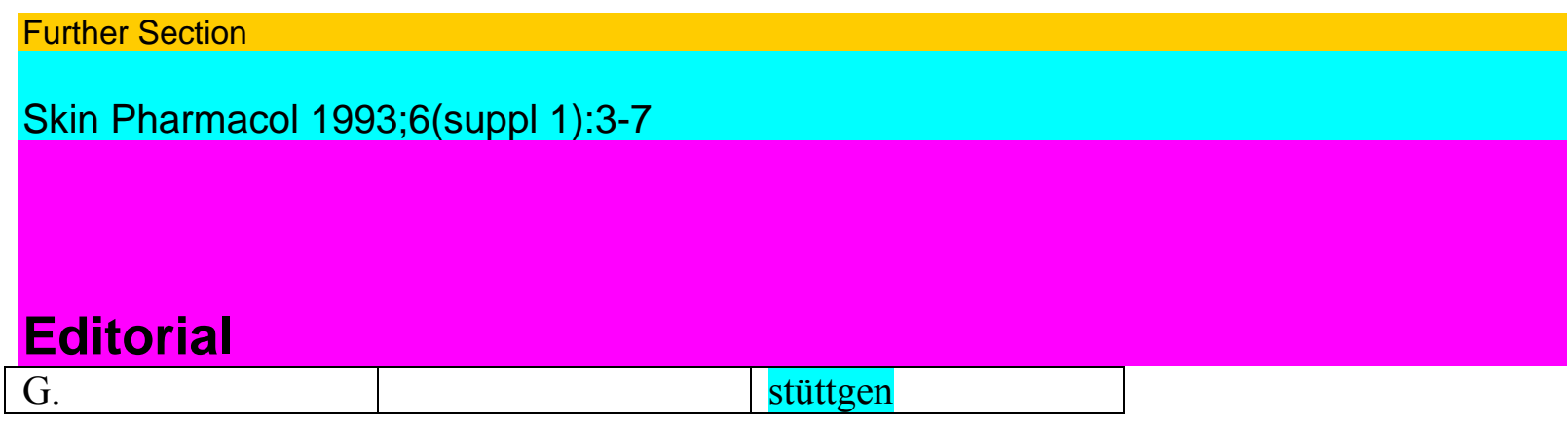

Berlin, FRG

From a clinical point of view, therapy with vitamin A acid originates from the thought that different pharmacokinetics of retinol in systemic or topical treatment would correspondingly entail a different metabolization and development of derivatives of vitamin A acid. Tumor development in the skin of mice caused by benzpyrene as well as therapy of ichthiosiform keratoses indicated that a therapeutic effect can only be achieved with systemic retinol administration. Henceforth, retinol metabolites applied topically resulted only in effects equivalent to those of systemic retinol treatment. Furthermore, clinical administration of tretinoin showed pharmacological characteristics exceeding the effect of retinol. The vitamin A story began in 1958/ 1959 with the discovery of its efficacy in retention hyperkeratoses and in senile (actinic) keratoses [1] and also its influences on normal skin with 'smoothing' effects on the skin surface. Topical tretinoin $(0.05 \%)$ treatment of photoaged skin with atrophy, wrinkles and pigmentation by Kligman et al. [2] and the confirmation and consolidation by Ellis and Voorhees [3] inaugurated a new area in scientific dermatologic cosmetology. The clinical indications for treatment with tretinoin had to be compiled from an increasing number of anecdotic individual cases, in which keratinization processes of malign as well as of benign nature showed therapeutic results. Furthermore, the stimulation of a lymphocytic infiltration of epithelial malignancies was soon related to immunologic parameters [4] (fig. 1-3).

In a daily dose of $100 \mathrm{mg}$ orally, tretinoin suggested a therapeutic effect, which was generally more pronounced in retention keratoses. In the field of oncology, cancer en cui-rasse and multiple basaliomas showed a decrease in proliferation kinetics [4-6]. Individual adverse effects as severe edema on the 2nd day of administration (psoriasis) or unconsciousness lasting for 4 days with a completely stable circulatory system and subsequent awakening without complications necessitated careful observation exceeding the already present toxicological data. In retrospect, these side effects can be attributed to the tox-icity of tretinoin, which is higher than that of the synthetic retinoids of today.

Local treatment was followed by skin irritations, which have their own problems in dermatologic practice; this situation was basically changed when Kligman et al. [7] introduced the local treatment of acne with isotre-tinoin in 1969. In 1978/1979, Peck et al. [8] initiated the oral treatment of cystic acne.

Prof. Dr. med. G. Stüttgen (C) 1993

Kissinger Strasse 12 S. Karger AG, Basel

D-14199 Berlin(FRG) 1011-0283/93/

0O65-OO03S2.75/O

Fig. 1. Tumor induced by benz-pyren. The beginning of vitamin A acid research in Düsseldorf in 1958. 
Fig. 2. First figure of improvement of congenital ichthyosiform erythroderma by topical vitamin A acid, verum against placebo (Düsseldorf, 1959).

Already in 1971, we recognized the superiority of isotretinoin (given orally: $10 \mathrm{mg}$ ) compared to tretinoin and informed La Roche of the pronounced scaling effect by topical application of isotretinoin $(0.1-0.5 \%)$ on the horny layer. There, Bollag $[9,10]$ was the stimulator and constant advisor of our examinations limited to tretinoin, which was supplied by La Roche as well as BASF. The main efforts of La Roche concentrated on isotretinoin in Nutley, N.J., USA, while etreti-nate predominated in Europe. Bollag's [10] model of papillomas enabled the differentiation of retinoids always keeping oncological efficacy in mind [5]. The Symposium on Vitamin A Acid in Flims in 1975 revealed new perspectives [11]. The break in therapy of psoriasis developed shortly after this by way of oral etretinate [12]. The differentiation with respect to clinical aspects already indicated that the missing inhibition of sebum secretion by etretinate [13] could be attributed to a differentiation in receptors. The presentation of various receptors on protein and gene level [14-16] ocurred concomitantly with the determination of the pharmacological spectrum. Vitamin A acid and its derivatives showed similarities to the nuclear receptors of thyrox-

4

Stüttgen

Editorial

Fig. 3. Erysipelas carcinomatosa treated orally with $100 \mathrm{mg}$ vitamin A acid daily and topically with 1\% vitamin A acid ointment daily (Berlin, 1970). a Before treatment, b One month later, c Two months later. By histology, the improvement in the condition was documented only in the upper regions of the tumor. In the deeper layers $(2 \mathrm{~mm})$ an influence on the tumor cells with some nuclear pyknoses and vacuolic degeneration.

ine and steroids, which belong to the super-family of nuclear hormonal receptors [17]. The synthetic retinoids proved that a change in the binding capacity is combined with changes in receptor selection and thus a differentiation in efficacy. The dose-dependent teratogenicity will remain a basic phenomenon, whereas the affinity of keratinocyte receptors, microvascular endothelial cells and the modulation of the immune system are changing phenomena which depend on the characteristics of each retinoid [18, 19]. In the skin, retinoids can be inactivated or converted to other active compounds, e.g. to isotretinoin after photoisomerization of topical tretinoin [20]. The problem of dose-dependent activities of the immune system was documented by inhibiting or activating effects of the same system on interleukin 2 . The molecular mechanism in the treatment of the skin 5

Table 1. A concept of the multifactorial action of retinoids

\begin{tabular}{|c|c|}
\hline Synthetic retinoids & Tretinoin $<$ Retinol \\
\hline & $\begin{array}{l}\text { Variable receptor binding (CRBP, CRABP, RAR, RXR) } \\
\text { on target cells and type of retinoids with effects on: }\end{array}$ \\
\hline $\begin{array}{l}\text { Cell differentiation and } \\
\text { proliferation } \\
\text { (keratinocvtes. skin } \\
\text { neonlastic tissue) }\end{array}$ & $\begin{array}{l}\text { Immune system Morphogenetic } \\
\text { (B lvmphocvtes. action } \\
\text { T lvmnhocvtes. } \\
\text { cvtokines macronhages) }\end{array}$ \\
\hline
\end{tabular}


$\Phi$

Normalization of tissue homeostasis and

Examples of indication:

Hvperkeratosis

Acne

Ichthvosiform keratosis

Psoriasis

Photoaging

Melasma

Keratoakanthomas
$\Phi \Phi$

$\stackrel{\Phi}{\text { Membrane integrity }}$

Immune modulation

Anticarcinogenesis (reversible inhibition

of promotion.

Antiphlogistic action

Cancer-nreventing

Basalioma. xeroderma

pigmentosum

with topically applied retinoids can be explained by their influence on mesenchymo-epidermal interactions, activities on enzymes (e.g. transglutaminase) and finally by their influence on endothelial cells and angiogene-sis of the microcirculation [2,21]. The different effects of systemic or topical treatment encompass their own special problems. Topical application of tretinoin additionally to systemic therapy with retinoids can lower the systemic dose (table 1). Today, clinical aspects and assessment of biochemistry and molecular biology lay the foundation for the support and development of the ideal selective and specific therapy. This development is dependent on the creativity of 'abstract' scientists and experimental clinicians in order to meet the demands of the present society. This trend has also developed in the field of retinoids. It was a long way from the clinical observation, and 'simple' clinical aspects and the combined 'coincidental' therapeutical success to the recognition of the molecular structure of an hierarchical biological system to which the effect of retinoids can be counted today. The effect of retinoids as morphogenes underlines this situation which is integrated in the evolution of biological systems. Historical research on retinoids reveals that every retinoid has its own efficacy profile and spectrum of toxic effects. This information may, in the future, lead us to discover compounds with better therapeutic selectivity.

Today, importance of skin functions can be extended by the influence of retinoids on the skin associated lymphoid tissue or the skin immune system.

\section{Stüttgen Editorial}

The future role of retinoids does not only depend on monotherapy, retinoids can also participate as adjuvants to other therapeutical measures. The elementary mode of action of retinoids also changes the therapeutic threshold for other therapeutical principles. Skin and skin appendages are currently in the foreground of therapy. However, the therapeutic benefits in acute promyelocytic leukemia and in immune diseses, such as erythematodes for example, open the door to therapy in general. The following contributions based on several symposia and special chapters in books on advances in retinoids indicate examples for such aspects in the future [11,18-27].

\section{References}

Stüttgen G: Zur Lokalbehandlung von Keratosen mit Vitamin-A-Säu-re. Dermatologica 1962;124:65-80.

Kligman AM, Grove GL, Hirose R, Leyden JJ: Topical tretinoin for photoaged skin. J Am Acad Derma-toll986;15(suppl):836-859.

Ellis CN, Voorhees JJ: The treatment of actinically aged skin with topical tretinoin; in Reichert U, Shroot B (eds): Pharmacology of Retinoids in the Skin. Basel, Karger, 1989, pp 249-259. 
Schumacher A, Stüttgen G: Vita-min-A-Säure bei Hyperkeratosen, epithelialen Tumoren und Akne. Dtsch Med Wochenschr 1971;40: 1547-1551.

Epstein JH: All-trans-retinoic acid and cutaneous cancers. J Am Acad Dermatol 1986;15:772778.

Stüttgen G, Mahrle G: Oral vitamin A acid in treatment of dermatoses with pathologic keratinization. Int J Dermatol 1977; 10:500-502.

Kligman AM, Fulton JE Jr, Plewig G: Topical vitamin A acid in acne vulgaris. Arch Dermatol 1969;99: 469-476.

Peck GL, Olsen TG, Yoder FW, et al: Prolonged remission of cystic and conglobate acne with 13-cis-retinoic acid. N Engl J Med 1979;300:329-333.

Bollag W: From vitamin A to retinoids. Chemical and pharmacological aspects; in Orfanos CE, Braun-Falco O, Farber EM, Grupper CH, Polano MK, Schuppli R (eds): Retinoids: Advances in Basic Research and Therapy. New York, Springer, 1981, pp5-11.

Bollag W: Prophylaxis of chemically induced papillomas and carcinomas of mouse skin by vitamin A acid. Experientia 1972;28:1219-1220.

Stüttgen G, Braun-Falco O, Kligman AM, et al: The therapeutic use of vitamin A acid. Acta Derm Ven-ereol Suppl (Stockh) 1975;55.

Ott F, Bollag W: Therapie der Psoriasis mit einem oral wirksamen neuen Vitamin-A-Säure Derivat. Schweiz Med Wochenschr 1975; 105:439-442.

Strauss JS, Stranieri AM, Farrell LN, et al: The effect of marked inhibition of sebum production with 13-cis-retinoic acid on skin surface lipid composition. J Invest Dermatol 1980;74:66-67. Pfahl M: A nuclear receptor for reti-noic acid expressed in epithelial tissues and implicated in hepatocellu-lar carcinoma development; in Reichert U, Shroot B (eds): Pharmacology of Retinoids in the Skin. Basel, Karger, 1989, pp 68-73.

Tomic-Canic M, Sunjevaric I, Freedberg IM, Blumenberg M: Identification of the retinoic acid and thyroid hormone receptor-responsive element in the human K14 keratin gene. J Invest Dermatol 1992; 99:842-847.

Siegenthaler G, Saurat JH: Retinoid binding proteins and human skin. Pharmacol Ther 1989;40:45-54.

Krust A, Kastner PH, Petkovich M, Zelent A, Chambon P: A third human retinoic acid receptor. hRAR-gamma. Proc Natl Acad Sci USA 1989;86:5310-5314.

Current Aspects of Systemic Retinoid Therapy (18th Supplement): Retinoids Today and Tomorrow. Proceedings of the Satellite Symposium to the 1st Congress of the European Academy of Dermatology and Venereology. Florence, Mediscript, 1989.

Retinoids: Present and Future. 18th World Congress of Dermatology, New York, 1992. Reichert U, Shroot B (eds): Pharmacology of Retinoids in the Skin. 8th CIRD Symposium on Advances in Skin Pharmacology, Cannes, September 1988. Basel, Karger, 1989. Topical retinoids: An update. Proceedings of a symposium, 1986, New York. J Am Acad Dermatol 1986;15(suppl).

Merk HG, Bickers DR: Dermato-pharmacology and Dermatotherapy. Vitamin A and the retinoids. Berlin, Blackwell, 1992, pp 233-254.

Cunliffe WJ, Miller AJ (eds): Retinoid Therapy. Lancaster, MTP Press, 1983.

Sporn MB, Roberts AB, Goodman DS, et al (eds): The Retinoids. Orlando, Academic Press, 1984. 
Orfanos CE (ed): Recent Development in Clinical Research. Curr Probl Dermatol. Basel, Karger, 1985 , voll3.

Saurat JH (ed): Retinoids. New Trends in Research and Therapy. New York, Karger, 1984.

Orfanos CE, Braun-Falco O, Farber EM, Grupper Ch, Polano MK, Schuppli R (eds): Retinoids Advances in Basic Research and Therapy. Berlin, Springer, 1981. 